\title{
STRENGTH AND EROSION OF LIME STABILIZED GYPSEOUS SOIL UNDER DIFFERENT FLOW CONDITIONS
}

\author{
Abdulrahman H. T. Al-Zubaydi \\ Assistant Lecturer \\ University of Mosul- College of Engineering
}

\begin{abstract}
This work aims to study the effect of erosion on the strength, loss in weight and gypsum dissolution of gypseous soil stabilized with (4\%) lime, take into account the following variables: initial water content, water temperature, soaking duration or flow duration and water velocity. The results indicate that, the unconfined compressive strength decreased for samples soaked in water have low temperature $\left(5^{0}\right.$ and $\left.25^{\circ} \mathrm{C}\right)$, further decrease in strength with increasing soaking duration. The higher water temperatures $\left(49^{\circ}\right.$ and $\left.60^{\circ} \mathrm{C}\right)$ showed increasing in the unconfined compressive strength. High water velocity causes decreasing in unconfined compressive strength, more loss in weight and more loss in gypsum content, for all values of flow duration and water temperature.
\end{abstract}

Key Words: Gypseous soil, Lime stabilization, Strength, Erosion.

$$
\begin{aligned}
& \text { المقاومة والتعرية للتربة الجبسية المثبتة بالنورة تحث ظروف جريان متغيرة } \\
& \text { عبدالرحمن هاتي طاءه الزبيدي }
\end{aligned}
$$

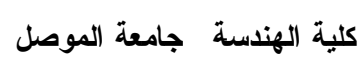

\section{الخلاصة}

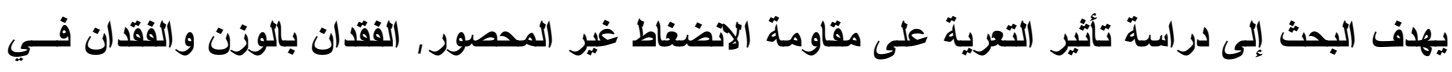

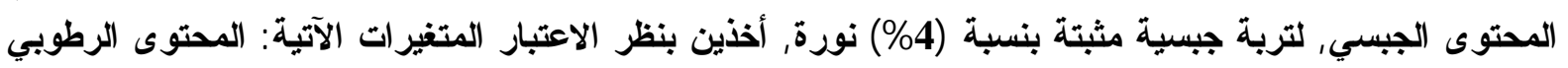

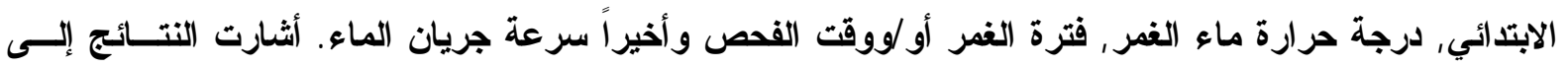

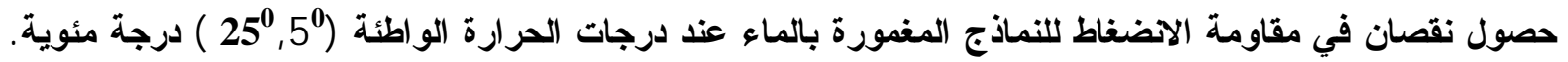
فيما ازدادت هذه المقاومة عند درجات حرارة الماء العالية (60

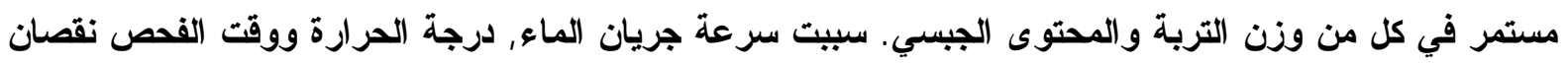

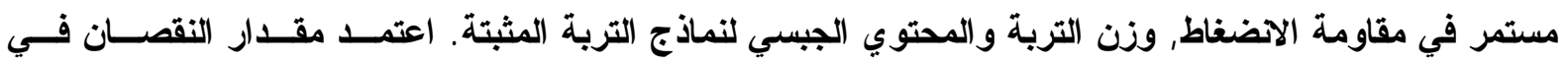

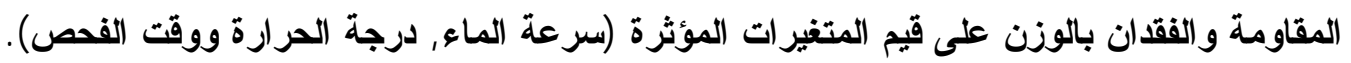

Received : $13-5-2009$

Excepted : $25-4-2010$ 


\section{INTRODUCTION.}

About one - third of the World 's land surface lies within the arid climatic zone. In most regions, natural soil and aggregates contain varying quantities of soluble salts $[1,2,3]$. Gypsum is one of these salts, which has a detrimental effect on pavement, foundation and earth structures [4]. Gypseous soils occupy about $20 \%$ of the total area in Iraq, which is equivalent to about $7.3 \%$ of the total area of gypsiferous soils in the world [3]. In dry soil, the gypsum acts as a cementing material. However, the intrusion of water through rain fall, rise in the ground water table or leakage through canal linings may result in dissolution of gypsum and softening of soils that can lead to a serious damage and even collapse of structures founded on such soils [5,6,7], Moreover, gypseous soils are very sensitive to moisture, complete collapse and reduction in the bearing capacity are anticipated when ever they get into contact with water. There are many situations where the ground water table is very high or the subgrade soil is subjected to long-term flood or soaking. In situations where ground water flow is near the ground surface, the dissolution of the total soluble salt in the subgrade can lead to serious volume changes leading to loss of strength $[8,9,10,11]$. The rate of dissolution of gypsum is very sensitive to many parameters such as temperature, salinity, water volume and velocity of water flow $[12,13,14]$. James and Kirkpatrik [15] pointed out that the solubility of gypsum in pure water at $\left(10{ }^{\circ} \mathrm{C}\right)$ is $2.5 \mathrm{~kg} / \mathrm{m}^{3}$. According to James and Lupton [16], the solution rate of gypsum depends on the concentration of salts in solution, flow rate and temperature. This rate increase linearly as the flow velocity increases and as the concentration of sodium chloride increases. To improve the strength of gypseous soils and reduce the problems related to gypsum dissolution, lime treatment has been used [17]. Moreover, lime treatment is one of the most economical techniques to improve the engineering properties of gypseous soils.

This research aims to study the effect of soaking and velocity of water flow under different temperature on the unconfined compressive strength, loss of weight and gypsum dissolution of gypseous soil stabilized with optimum lime percent.

\section{Experimental Program.}

\subsection{Materials Used.}

- Soil.

The soil used in this study is a gypseous soil having (20\%) gypsum content, obtained from a region near $\mathrm{Al}-$ Hader district about $(80 \mathrm{~km})$ from Mosul city, at $(2.0 \mathrm{~m})$ below the ground surface. Table (1) shows some of the index properties and chemical tests of the soil, using the relevant tests according to the ASTM standards.

Table (1) chemical \& physical properties of natural soil

\begin{tabular}{|l|c|}
\hline \multicolumn{1}{|c|}{ Properties } & Values \\
\hline Liquid Limit (\%) & 46 \\
\hline Plastic Limit (\%) & 22 \\
\hline Plasticity Index (\%) & 24 \\
\hline Total Soluble salts (\%) & 29.0 \\
\hline $\mathrm{SO}_{3}{ }^{\circ}(\%)$ & 0.39 \\
\hline$*$ Gypsum content (\%) & 20.0 \\
\hline Organic content (\%) & 1.02 \\
\hline Specific Gravity & 2.58 \\
\hline Sand (\%) & 10 \\
\hline Silt (\%) & 40 \\
\hline Clay (\%) & 50 \\
\hline Soil Classification & $\mathrm{CL}$ \\
\hline
\end{tabular}


* Gypsum content was found using chemical method which depend on the titration by EDTA (Ethylene Diamine Tetra Acetic). (B.S 1377)

- Lime.

The lime used in this study is high - calcium hydrated lime (76\% activity), was obtained from Meshrag Sulphur factory. The chemical analysis of the lime is shown in Table (2).

Table (2) chemical composition of lime

\begin{tabular}{|c|c|c|c|c|c|c|c|l|l|}
\hline Composition & $\mathrm{Ca}(\mathrm{OH})_{2}$ & $\mathrm{CaO}$ & $\mathrm{CaCO}_{3}$ & $\mathrm{AL}_{2} \mathrm{O}_{3}$ & $\mathrm{Fe}_{2} \mathrm{O}_{3}$ & $\mathrm{SiO}_{2}$ & $\mathrm{MgO}$ & $\mathrm{H}_{2} \mathrm{O}$ & L.O.S \\
\hline lime & 73.0 & 6.1 & 5.2 & 0.17 & 0.04 & 10.1 & 4.19 & 0.09 & ----- \\
\hline
\end{tabular}

- Water.

Tap water was used in the preparation of samples and in testing.

\subsection{Tests Procedures}

\subsubsection{Samples Preparation.}

An experimental program was performed on gypseous soil samples, which was treated by adding varying percentages of lime $(2,4$, and $6 \%)$ by dry weight of soil. Firstly, the soil was oven dried for (2) days at $60{ }^{0} \mathrm{C}$, then mixed with required amount of lime and water, which was sprayed and remixed thoroughly. The mixing continued until the final mixture gets a uniform moisture distribution. The mixture was then placed in plastic bags and kept in a humidity controlled room for mellowing time of (24) hours for untreated, and (1) hour for treated soil [18]. Thereafter, the mixture was compacted in a specific mold of each types of the required testing. A modified compactive effort was considered.

\subsubsection{Unconfined Compression Test.}

Unconfined compression tests were performed on compacted samples treated with $(0,2,4$, and $6 \%)$ lime. All the treated samples were cured for two days at $\left(49^{0} \mathrm{C}\right)$. The samples tested at a rate of $(1.27 \mathrm{~mm} / \mathrm{min}$.) following the procedure of ASTM (D-2166).

\subsection{Erosion Test.}

Erosion test is one of the durability tests, which was used to examine the ability of stabilized soils to resist the climatic and environmental conditions. The effect of erosion on unconfined compressive strength $\left(\mathrm{q}_{\mathrm{u}}\right)$, loss in weight and loss in gypsum content in soil samples subjected to different values of molding water content, i.e, OMC and $\mathrm{OMC} \pm 3.0 \%$ ( denoted as dry side (D.S) and wet side (W.S)) has been examined. Two approaches have been suggested to examine the aforementioned properties of the lime stabilized samples against erosion test; first approaches is the long - term soaking (immersion in static water) under different water temperature $\left(5^{\circ}, 25^{\circ}, 49^{\circ}\right.$ and $\left.60^{\circ} \mathrm{C}\right)$. In this approach, a cylindrical samples (50 mm dia. x $100 \mathrm{~mm}$ height) were immersed in glass container (desiccators) with referee cover for $(2,7,14,28,56$ and 90) days. After the end of soaking period, the samples were tested to find the unconfined compressive strength. The tested sample was dried for two days to find the loss in gypsum content using chemical method which depend on the titration by EDTA. The dropped soil from sample surfaces in container bottom at each soaking period was collected to find the percent of loss in weight. The soaking water was changed continuously at a certain rate ( 3 days) to avoid the saturation of gypsum in the water.

In the second approach, the stabilized samples have been subjected to flowing water under different values of water temperature $\left(25^{\circ}, 49^{\circ}\right.$ and $\left.60^{\circ} \mathrm{C}\right)$, velocity $(0.05 \mathrm{~m} / \mathrm{sec}-1.2$ $\mathrm{m} / \mathrm{sec}$ ) and flow duration $(15,30,60,120$ and $240 \mathrm{~min}$.). In this test a hollow cylindrical 
samples (50 mm dia. x $100 \mathrm{~mm}$ height) was used. The hole was made along the length, with a diameter equal to $(5 \mathrm{~mm})$, with electrical drill. Then, A device manufactured by ( $\mathrm{Al}-$ Aarrajy)[19], as shown in plate (1) was used.

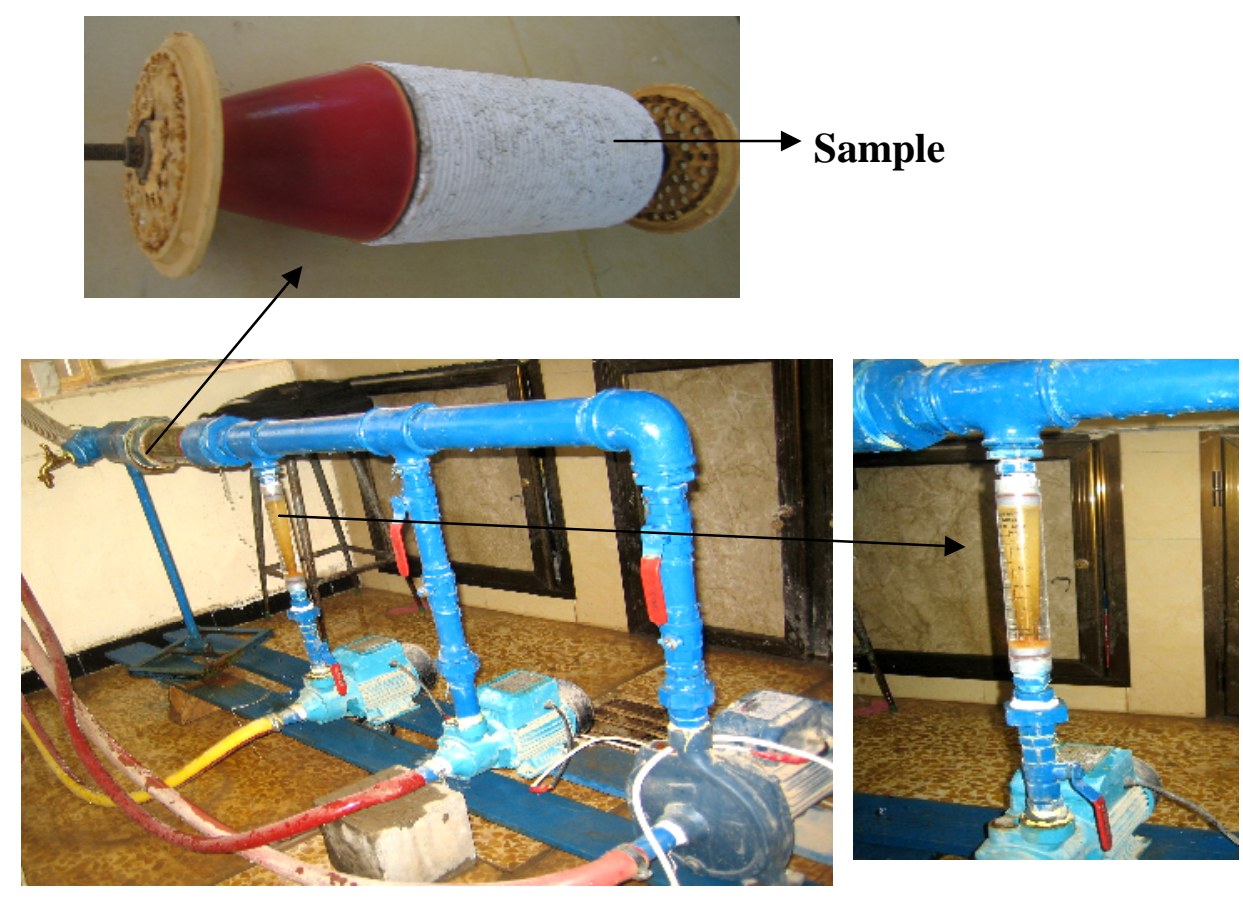

Flow meter

Plate (1) Testing device

Two sets of three samples each were prepared to study the effect of flowing water on the stabilized samples. The first set to determine the loss in weight and residual gypsum content, while the second set to evaluated the unconfined compressive strength. At the beginning, the sample was fixed in the cell, and the bases area of the sample (i.e. top and bottom) coated with adhesive impervious material such as silicon to control the area of erosion. After that, the sample subjected to flowing water under different velocities $(0.05,0.1,0.2,0.4,0.8$, and $1.2 \mathrm{~m} / \mathrm{sec})$ and temperature $\left(25^{\circ}, 49^{\circ}\right.$ and $\left.60^{\circ} \mathrm{C}\right)$ for $(15,30,60,120$ and $240 \mathrm{~min}$.). At the end of the test, the first set of samples were extracted from the cell and dried for (2 days) at $\left(60^{\circ} \mathrm{C}\right)$ to obtain the dry weight to estimate the percent of loss in weight. Then these samples were tested to find the residual gypsum content using chemical method which depend on the titration by EDTA (Ethylene Diamine Tetra Acetic). However, the second set of the samples were tested to find the unconfined compressive strength (tested in saturated state).

\section{Results and Discussion.}

\subsection{Compaction Characteristics.}

Figure (1) presents the results of the compaction tests on the untreated and treated gypseous soil with different percentages of lime $(0,2,4$ and $6 \%)$. The maximum dry unit weight $\left(\gamma_{\mathrm{d} \text { max }}\right)$ decreases with the addition of lime, and the optimum moisture content (OMC) increases. This reduction results due to the immediate reactions between lime and clay particles, which is represented by flocculation and agglomeration. The increase of (OMC) with increasing lime percent may be due to the more added fine materials and/or to the hydration of the lime. This behavior have been reported by ( $\mathrm{Al}$ - Obydi)[17] . 


\subsection{Unconfined Compressive Strength.}

The unconfined compressive strength $\left(\mathrm{q}_{\mathrm{u}}\right)$ results are presented in Fig. (2) for natural (untreated) and lime treated soils. This figure indicates that the max. value of $\left(\mathrm{q}_{\mathrm{u}}\right)$ for natural soil was $\left(1054 \mathrm{kN} / \mathrm{m}^{2}\right)$, and this value occurred at a moisture content lower than the optimum one (i.e dry side). It is observed that the addition of lime has increased the strength of stabilized samples, This belongs to the reaction that may occur between the soil constituents and lime. The maximum unconfined compressive strength $\left(\mathrm{q}_{\mathrm{u}}\right)$ values were $(2808,3573$ and $\left.2921 \mathrm{kN} / \mathrm{m}^{2}\right)$ for $(2,4$ and $6 \%$ lime) respectively with an improvement ratio being $(2.66,3.38$ and 2.77) times that of the untreated samples. The water content (w/c) for lime stabilized samples, corresponding to the max. value of $\left(\mathrm{q}_{\mathrm{u}}\right)$ was on the wet side. Similar behavior have been reported by $(\mathrm{Al}-$ Obydi)[17] .

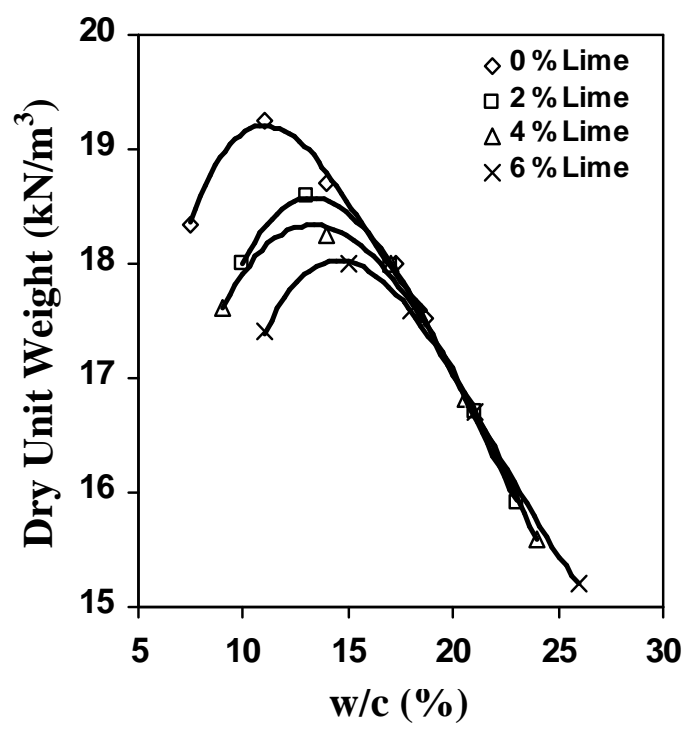

Fig. (1) Compaction characteristics curves for natural and lime treated soils

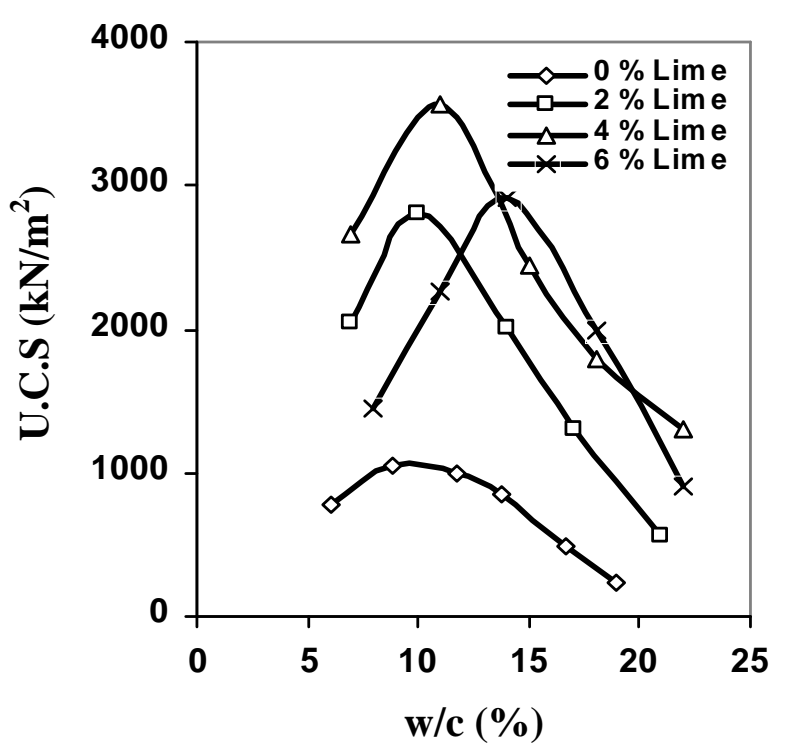

Fig. (2) Unconfined compressive strength curves for natural and lime treated soils

Table (3) (\%) loss in weight of lime stabilized gypseous soil

\begin{tabular}{|c|c|c|c|c|c|c|c|}
\hline \multirow{2}{*}{$\begin{array}{c}\text { Temp. } \\
\left(\mathbf{C}^{\mathbf{0}}\right)\end{array}$} & $\begin{array}{c}\text { Initial water } \\
\text { content }(\mathbf{\%})\end{array}$ & \multicolumn{6}{|c|}{ Soaking Duration (day) } \\
\hline \multirow{3}{*}{$\mathbf{5}^{\mathbf{0}}$} & $\mathbf{D . S}$ & 0.07 & $\mathbf{7}$ & $\mathbf{1 4}$ & $\mathbf{2 8}$ & $\mathbf{5 6}$ & $\mathbf{9 0}$ \\
\cline { 2 - 8 } & $\mathbf{O . M . C}$ & 0.04 & 0.087 & 0.113 & 0.76 & 1.0 & 1.43 \\
\cline { 2 - 8 } & W.S & 0.04 & 0.073 & 0.096 & 0.54 & 0.89 & 1.21 \\
\hline \multirow{3}{*}{$\mathbf{2 5}^{\mathbf{0}}$} & D.S & 0.09 & 0.23 & 0.91 & 1.78 & 2.32 & 3.36 \\
\cline { 2 - 8 } & $\mathbf{O . M . C}$ & 0.063 & 0.091 & 0.16 & 0.88 & 1.2 & 1.67 \\
\cline { 2 - 8 } & W.S & 0.051 & 0.085 & 0.131 & 0.73 & 1.0 & 1.32 \\
\hline \multirow{3}{*}{$\mathbf{4 9}^{\mathbf{0}}$} & D.S & 0.1 & 0.32 & 1.12 & 1.86 & 2.47 & 3.73 \\
\cline { 2 - 8 } & O.M.C & 0.094 & 0.15 & 0.89 & 1.33 & 1.77 & 2.0 \\
\cline { 2 - 8 } & W.S & 0.09 & 0.13 & 0.66 & 0.92 & 1.23 & 1.85 \\
\hline \multirow{3}{*}{$\mathbf{6 0}^{\mathbf{0}}$} & D.S & 0.12 & 0.41 & 1.23 & 2.0 & 2.88 & 4.65 \\
\cline { 2 - 8 } & O.M.C & 0.11 & 0.2 & 1.13 & 1.84 & 2.21 & 2.77 \\
\cline { 2 - 8 } & W.S & 0.097 & 0.178 & 1.0 & 1.41 & 1.85 & 2.0 \\
\hline
\end{tabular}




\subsection{Effect of Soaking in Static Water.}

The soaking in static water aims to study the unconfined compressive strength $\left(\mathrm{q}_{\mathrm{u}}\right)$, loss in gypsum content and loss in weight of lime stabilized gypseous soil under the following variables: water temperature $\left(5^{\circ}, 25^{\circ}, 49^{\circ}\right.$ and $\left.60^{\circ} \mathrm{C}\right)$, soaking duration $(2,7,14$, 28, 56 and 90 days) and initial moisture content (OMC (14\%) and OMC $\pm 3.0 \%)$. Table (3) shows the effect of soaking on the weight losses under different variables of water temperature and duration. It is observed that, the losses in weight increases with increasing water temperature and duration. The maximum values of weight losses occurred to the samples compacted in dry side of modified curve.

\subsubsection{The Unconfined Compressive Strength.}

Figures (3 and 4) and Table (4) show the effect of water temperature and soaking duration on the unconfined compressive strength $\left(\mathrm{q}_{\mathrm{u}}\right)$. A decrease in the unconfined compressive strength $\left(\mathrm{q}_{\mathrm{u}}\right)$ was obtained for soaked samples in water have low temperature $\left(5^{0}\right.$ and $25^{\circ} \mathrm{C}$ ), further decrease in strength was observed with increasing soaking duration. A decreasing of soaked samples for $(90)$ days at a temperature $\left(5^{\circ} \mathrm{C}\right)$ by almost $(80,77$ and 71 $\%$ ) of samples compacted at initial molding water content represented by (D.S, OMC and W.S) respectively. The water temperature $\left(25^{\circ} \mathrm{C}\right)$ gave decreasing ratios of $(46,52$ and $63 \%)$ compared with that of the unsoaked samples for the same above condition. This behavior may be due to the uncompleted pozzolanic reaction, and/or more dissolution of gypsum that might occurred by water change process which have been done every three days. The higher water temperature $\left(49^{0}\right.$ and $\left.60^{\circ} \mathrm{C}\right)$ showed increasing in the unconfined compressive strength $\left(q_{u}\right)$, where $\left(q_{u}\right)$ increased from $\left(3573,2800\right.$ and $\left.2000 \mathrm{kN} / \mathrm{m}^{2}\right)$ to $(4620,3850$ and 2750 $\mathrm{kN} / \mathrm{m}^{2}$ ) for $49^{0} \mathrm{C}$ water temperature at 28 days soaking for the initial moisture content (D.S, $\mathrm{OMC}$ and W.S) respectively. These values gave an improvement ratios (1.3, 1.38 and 1.38) times of the unconfined compressive strength of the unsoaked samples. The unconfined compressive strength increases from $\left(3573,2800\right.$ and $\left.2000 \mathrm{kN} / \mathrm{m}^{2}\right)$ for unsoaked samples to $\left(5210,4130\right.$ and $\left.3000 \mathrm{kN} / \mathrm{m}^{2}\right)$ for samples soaked at 28 days in $\left(60^{0} \mathrm{C}\right)$ water temperature for the initial moisture content (D.S, OMC and W.S) respectively. This gave an improvement ratios of $(1.46,1.48$ and 1.5) times of the unconfined compressive strength of the unsoaked samples. After (28) days soaking, the $\left(\mathrm{q}_{\mathrm{u}}\right)$ showed slightly decreasing in its values as shown in Table (4), and the rate of decreasing increased with soaking duration. However, after (90) days soaking in water at $\left(49^{\circ}\right.$ and $\left.60^{\circ} \mathrm{C}\right)$, the values of $\left(\mathrm{q}_{\mathrm{u}}\right)$ were $(3887,3447$ and 2489 $\left.\mathrm{kN} / \mathrm{m}^{2}\right)$ and $\left(4896,3800\right.$ and $2666 \mathrm{kN} / \mathrm{m}^{2}$ ) respectively, but these values remains higher than the strength values of unsoaked samples (i.e. 3573,2800 and $2000 \mathrm{kN} / \mathrm{m}^{2}$ ). The difference in the unconfined compressive strength $\left(\mathrm{q}_{\mathrm{u}}\right)$ between samples cured at $\left(25^{\circ}\right.$ and $\left.49^{\circ} \mathrm{C}\right)$ could be attributed to highly rate of reaction at $\left(49^{\circ} \mathrm{C}\right)$ compared with those cured at $\left(25^{\circ} \mathrm{C}\right)$. On the other hand, the effect of initial molding water content on the unconfined compressive strength $\left(\mathrm{q}_{\mathrm{u}}\right)$ have been illustrated in Table (4). It is observed that the compacted samples at water content represented the dry side of the modified compaction curve $(11.0 \%)$ has higher values of the $\left(\mathrm{q}_{\mathrm{u}}\right)$ under all soaking conditions.

\subsubsection{Loss in Gypsum Content.}

After the ending of the unconfined compression test, the failed sample was tested to fined the loss in gypsum content using chemical titration by EDTA (Ethylene Diamine Tetra Acetic) method. Results showed that the gypsum content in natural soil was decreased when lime was added to soil and cured for $(2)$ days at $\left(49^{0} \mathrm{C}\right)$. This percent decreased from $(20 \%)$ for natural soil to $(17.5 \%)$ for stabilized samples compacted in dry side and optimum 
moisture content, while the percent was decreased to $(18.0 \%)$ for samples compacted in wet side of the
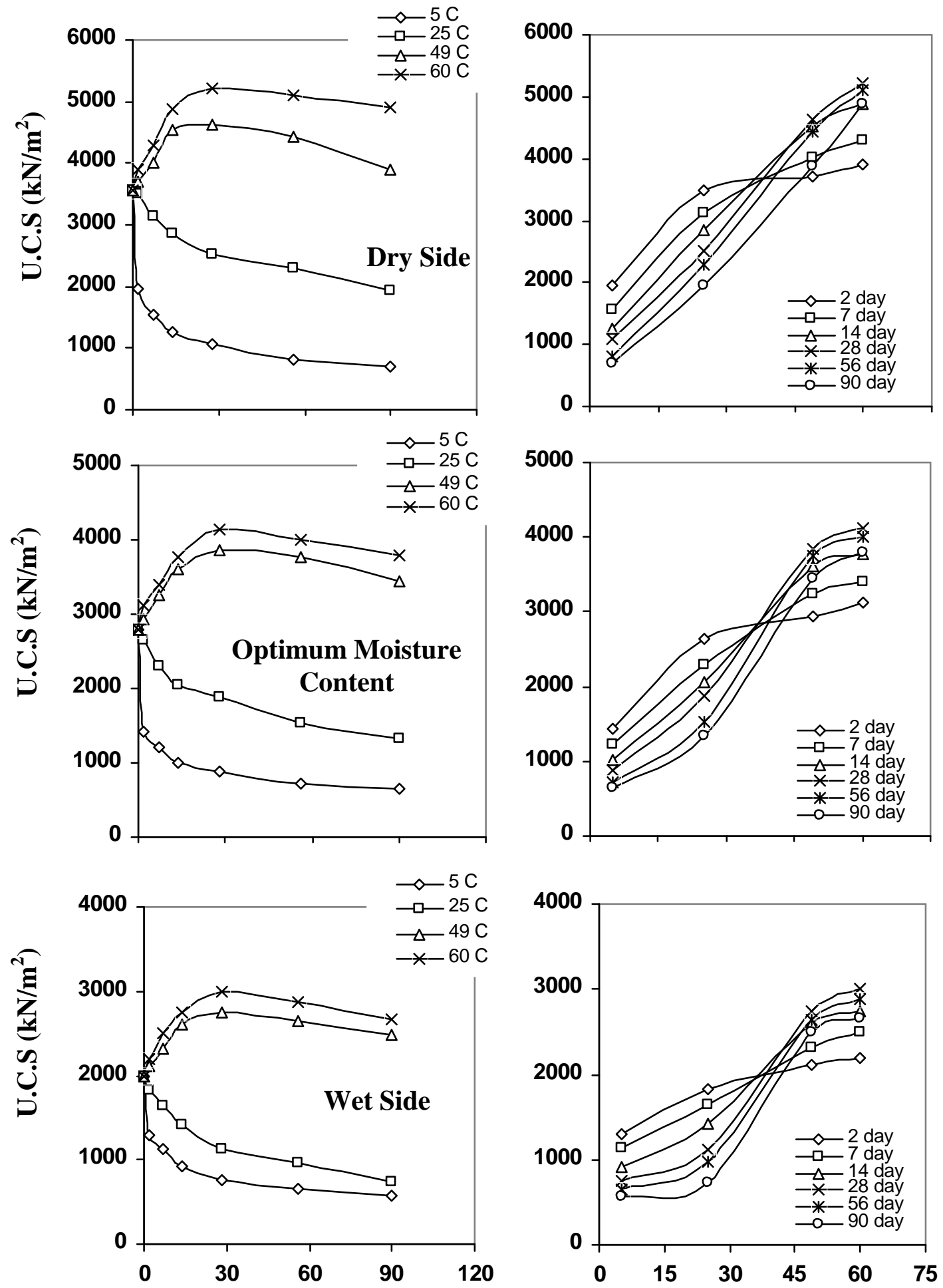

Soaking Duration

(day)

Water Temperature

$\left(\mathbf{C}^{\mathbf{0}}\right)$

Fig. (3) Correlation between UCS and soaking duration

Fig. (4) Correlation between UCS and water temperature 
Table (4) change in U.C.S values with soaking durations

\begin{tabular}{|c|c|c|c|c|c|c|c|}
\hline \multirow{2}{*}{$\begin{array}{l}\text { Soaking } \\
\text { Temp. } \\
\left(C^{0}\right)\end{array}$} & \multirow{2}{*}{$\begin{array}{c}\text { Soaking } \\
\text { Duration } \\
\text { (day) }\end{array}$} & \multicolumn{2}{|c|}{$\begin{array}{c}\text { Dry Side } \\
\text { (D.S) }\end{array}$} & \multicolumn{2}{|c|}{$\begin{array}{c}\text { Optimum } \\
\text { Moisture Content } \\
\text { (O.M.C) }\end{array}$} & \multicolumn{2}{|c|}{$\begin{array}{c}\text { Wet Side } \\
\text { (W.S) }\end{array}$} \\
\hline & & $\begin{array}{c}\text { U.C.S } \\
\left(\mathrm{kN} / \mathrm{m}^{2}\right)\end{array}$ & $\begin{array}{c}\text { Change } \\
(\%)\end{array}$ & $\begin{array}{c}\text { U.C.S } \\
\left(\mathrm{kN} / \mathrm{m}^{2}\right)\end{array}$ & $\begin{array}{c}\text { Change } \\
(\%)\end{array}$ & $\begin{array}{c}\text { U.C.S } \\
\left(\mathbf{k N} / \mathbf{m}^{2}\right)\end{array}$ & $\begin{array}{c}\text { Change } \\
(\%)\end{array}$ \\
\hline$*$ & $*$ & $3573 *$ & ---- & $2800 *$ & ----- & $2000 *$ & ---- \\
\hline \multirow{6}{*}{$5^{0}$} & 2 & 1956 & -45 & 1430 & -50 & 1300 & -35 \\
\hline & 7 & 1550 & -57 & 1220 & -56 & 1130 & -44 \\
\hline & 14 & 1248 & -65 & 1010 & -64 & 915 & -54 \\
\hline & 28 & 1078 & -70 & 875 & -69 & 760 & -62 \\
\hline & 56 & 810 & -77 & 710 & -75 & 647 & -68 \\
\hline & 90 & 700 & -80 & 643 & -77 & 573 & -71 \\
\hline \multirow{6}{*}{$25^{0}$} & 2 & 3500 & -2 & 2650 & -5 & 1820 & -9 \\
\hline & 7 & 3130 & -12 & 2300 & -18 & 1650 & -18 \\
\hline & 14 & 2850 & -20 & 2050 & -27 & 1420 & -29 \\
\hline & 28 & 2520 & -29 & 1875 & -33 & 1120 & -44 \\
\hline & 56 & 2300 & -36 & 1530 & -45 & 965 & -52 \\
\hline & 90 & 1943 & -46 & 1334 & -52 & 731 & -63 \\
\hline \multirow{6}{*}{$49^{0}$} & 2 & 3710 & +4 & 2940 & +5 & 2120 & +6 \\
\hline & 7 & 4010 & +12 & 3250 & +16 & 2315 & +16 \\
\hline & 14 & 4530 & +27 & 3600 & +29 & 2600 & +30 \\
\hline & 28 & 4620 & +29 & 3850 & +38 & 2750 & +38 \\
\hline & 56 & 4430 & +24 & 3760 & +34 & 2640 & +32 \\
\hline & 90 & 3887 & +9 & 3447 & +23 & 2489 & +24 \\
\hline \multirow{6}{*}{$60^{0}$} & 2 & 3900 & +9 & 3120 & +11 & 2200 & +10 \\
\hline & 7 & 4300 & +20 & 3400 & +21 & 2500 & +25 \\
\hline & 14 & 4870 & +36 & 3770 & +35 & 2750 & +38 \\
\hline & 28 & 5210 & +46 & 4130 & +48 & 3000 & +50 \\
\hline & 56 & 5100 & +43 & 4000 & +43 & 2877 & +44 \\
\hline & 90 & 4896 & +37 & 3800 & +36 & 2666 & +33 \\
\hline
\end{tabular}

* control sample cured for $(2)$ days at $\left(49^{0} \mathrm{C}\right)$

These reductions may be due to some part of gypsum sharing in pozzolanic reaction (Hunter) [20]. Table (5) shows the variation of gypsum content with soaking duration for different water temperatures and initial water content. The dissolved gypsum shows a gradual decrease with the soaking duration up to a certain period (i.e. 28 days), after that shows insignificant changes. The temperature has significant effect on the amount of dissolved gypsum at the beginning of soaking, which reduces with the time. The residual gypsum content values for (90) days soaking were $(10.87,8.67,6.78$ and $6.21 \%):(10.5,8.12,6.1$ and $5.78 \%):(10.0,7.76,5.6$ and $4.74 \%)$ for $\left(5^{\circ}, 25^{\circ}, 49^{\circ}\right.$ and $\left.60^{\circ} \mathrm{C}\right)$ and initial water content represented (D.S, OMC and W.S) respectively. This behavior may be attributed to the increase the dissolved gypsum with increasing water temperature, similar behavior have been reported by James and Lupton [16]. It is worth mentioning that, the samples compacted at W.S have residual gypsum content less than samples prepared at OMC and D.S.

Finally, the loss in weight of lime stabilized samples was small as given in Table (3). The maximum values of the loss in weight were occurred after long soaking duration, higher water temperature and the water content represented the dry side (D.S). 


\subsection{Effect of Flowing Water.}

\subsubsection{Loss in Weight.}

Figures (5 and 6) and Table (6) show the effect of water velocity and time duration on the loss in weight of the lime stabilized samples compacted at OMC and W.S of modified compaction curve. It is clear that, there is an increasing rate of weight losses with the increasing of flow speed and duration.

Table (5) (\%) residual gypsum content of lime stabilized gypseous soil

\begin{tabular}{|c|c|c|c|c|c|c|c|}
\hline \multirow{2}{*}{$\begin{array}{c}\text { Soaking } \\
\text { Temp. } \\
\left(\mathbf{C}^{\mathbf{0}}\right)\end{array}$} & $\begin{array}{c}\text { Initial water } \\
\text { content }(\boldsymbol{\%})\end{array}$ & $\mathbf{2}$ & $\mathbf{7}$ & $\mathbf{1 4}$ & $\mathbf{2 8}$ & $\mathbf{5 6}$ & $\mathbf{9 0}$ \\
\cline { 3 - 8 } & $\mathbf{D . S}$ & 17.16 & 16.5 & 14.35 & 12.1 & 11.4 & 10.87 \\
\cline { 2 - 8 } $\mathbf{5}^{\mathbf{0}}$ & $\mathbf{O . M . C}$ & 17.0 & 16.23 & 13.92 & 11.86 & 11.0 & 10.5 \\
\cline { 2 - 8 } & W.S & 17.0 & 16.0 & 13.63 & 11.2 & 10.78 & 10.0 \\
\hline \multirow{3}{*}{$\mathbf{2 5}^{\mathbf{0}}$} & D.S & 16.87 & 15.34 & 13.2 & 11.12 & 10.0 & 8.67 \\
\cline { 2 - 8 } & O.M.C & 16.2 & 15.1 & 13.0 & 11.0 & 9.24 & 8.12 \\
\cline { 2 - 8 } & W.S & 16.1 & 14.9 & 12.71 & 10.85 & 9.0 & 7.76 \\
\hline \multirow{3}{*}{$\mathbf{4 9}^{\mathbf{0}}$} & D.S & 16.21 & 14.76 & 12.23 & 10.1 & 8.21 & 6.78 \\
\cline { 2 - 8 } & O.M.C & 15.93 & 14.22 & 12.01 & 9.93 & 8.0 & 6.1 \\
\cline { 2 - 8 } & W.S & 15.8 & 13.8 & 11.9 & 9.0 & 7.5 & 5.6 \\
\hline \multirow{3}{*}{$\mathbf{6 0}^{\mathbf{0}}$} & D.S & 15.86 & 14.0 & 11.75 & 9.45 & 7.85 & 6.21 \\
\cline { 2 - 8 } & O.M.C & 15.5 & 14.0 & 11.52 & 8.96 & 7.2 & 5.78 \\
\cline { 2 - 8 } & W.S & 15.3 & 13.5 & 10.9 & 8.0 & 6.63 & 4.74 \\
\hline
\end{tabular}

This may be due to increasing erosion of the surface of the sample, which was obtained during the test. On the other hand, the loss in weight for the samples compacted at OMC was greater than those compacted at W.S. The max. values of the loss in weight for the higher water velocity $(1.2 \mathrm{~m} / \mathrm{sec})$ and long flow duration $(240 \mathrm{~min}$.) were found to be between $(8.0-27 \%)$ and $(6.5-17 \%)$ for samples compacted at OMC and W.S respectively.

The values of the weight loss of the stabilized samples under different values of water temperature have been illustrated in Figs. (7 and 8) and Table (6). A increasing in the loss in weight with increasing water temperature was observed. The percent of loss in weight for higher water velocity and long flow duration was increased from $(8.0 \%$ to $27 \%)$ and from $(6.5 \%$ to $17 \%)$, when water temperature increased from $\left(25^{\circ} \mathrm{C}\right.$ to $\left.60^{\circ} \mathrm{C}\right)$ for samples compacted at OMC and W.S respectively. There is a sudden increase in weight loss at $\left(49^{0} \mathrm{C}\right)$ compared with $\left(25^{\circ} \mathrm{C}\right)$. This is probably due to the more cation exchange between the water and treated soil. Therefore, the forces which tied these ions will weaken and this lead to accelerated in transition process of calcium $\left(\mathrm{Ca}^{++}\right)$and sulfate $\left(\mathrm{SO}_{4}{ }^{-2}\right)$ ions, then mixed with water ions (Elorza and Santolalla)[21].

\subsubsection{Unconfined Compressive Strength.}

The effect of flowing water on the unconfined compressive strength under different condition of water temperature, water velocity and flow duration, have been shown in Fig. (9). The results indicate, a slight decrease in the unconfined compressive strength $\left(\mathrm{q}_{\mathrm{u}}\right)$ with the velocity of water for compacted samples at OMC, higher decreasing was noted at the wet side. The $\left(\mathrm{q}_{\mathrm{u}}\right)$ of samples compacted at OMC and W.S decreased from $\left(2800 \mathrm{kN} / \mathrm{m}^{2}\right.$ to 2400 , 
2350 and $\left.2100 \mathrm{kN} / \mathrm{m}^{2}\right)$ and from $\left(2000 \mathrm{kN} / \mathrm{m}^{2}\right.$ to 1800,1600 and $\left.1430 \mathrm{kN} / \mathrm{m}^{2}\right)$ for water temperature $\left(25^{\circ}, 49^{\circ}\right.$ and $\left.60^{\circ} \mathrm{C}\right)$ respectively.

Optimum Moisture

\section{Content}
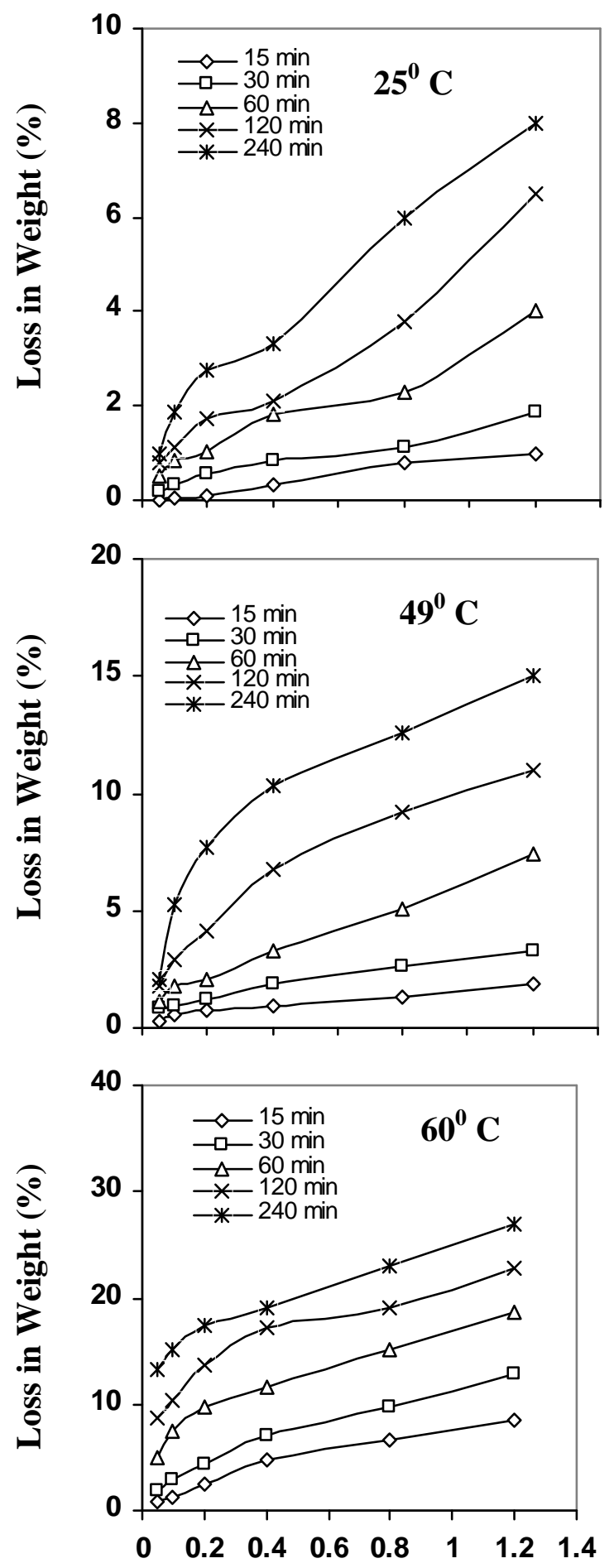

Water Velocity

$(\mathrm{m} / \mathbf{s e c})$
Wet Side
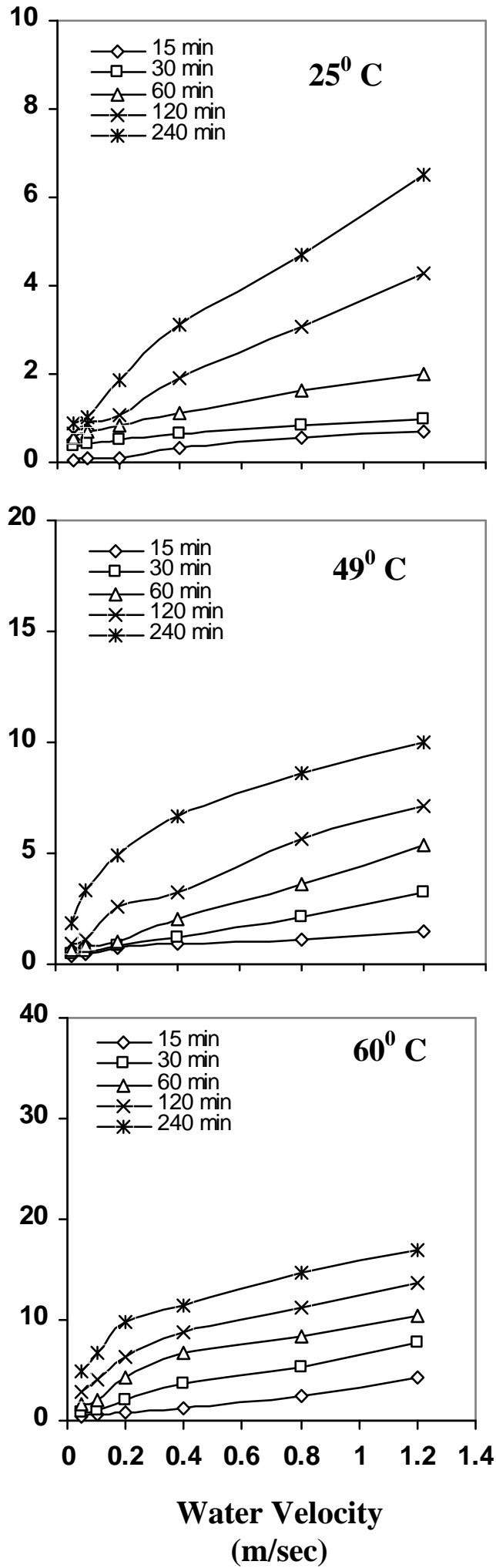

$(\mathbf{m} / \mathbf{s e c})$

Fig. (5) Correlation between loss in weight and water velocity 

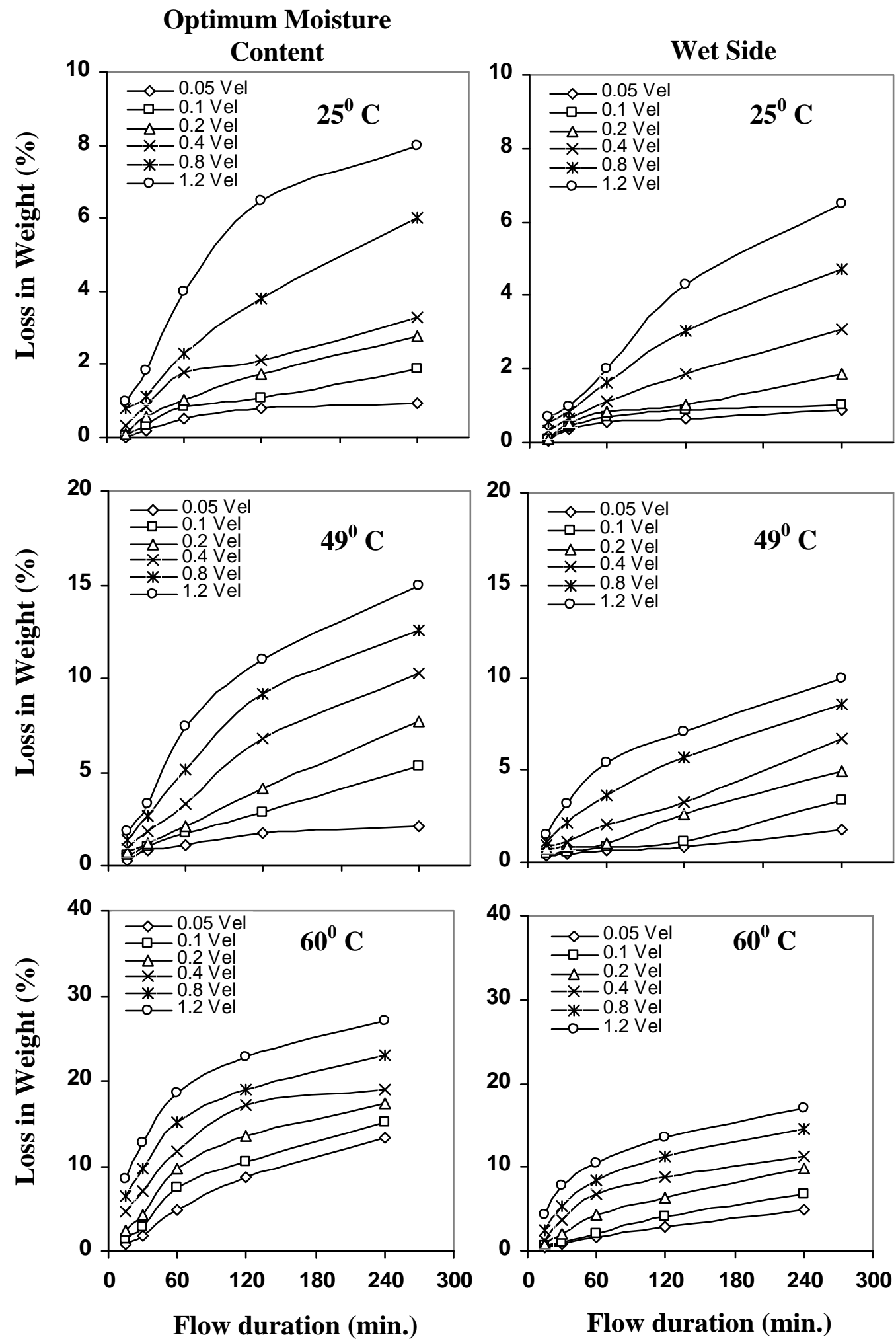

Fig. (6) Correlation between loss in weight and flow duration 
Table (6) (\%) loss in weight of lime stabilized gypseous soil.

\begin{tabular}{|c|c|c|c|c|c|c|c|c|}
\hline \multirow[b]{2}{*}{$\begin{array}{c}\text { Temp. } \\
\left(C^{0}\right)\end{array}$} & \multirow{2}{*}{$\begin{array}{c}\text { Initial } \\
\text { water } \\
\text { content } \\
(\%)\end{array}$} & \multirow{2}{*}{$\begin{array}{c}\text { Flow } \\
\text { durati } \\
\text { on } \\
\text { (min.) }\end{array}$} & \multicolumn{6}{|c|}{ Water Velocity $(\mathrm{m} / \mathrm{sec})$} \\
\hline & & & 0.05 & 0.1 & 0.2 & 0.4 & 0.8 & 1.2 \\
\hline \multirow{10}{*}{$25^{0}$} & \multirow{5}{*}{ O.M.C } & 15 & 0.008 & 0.06 & 0.1 & 0.32 & 0.78 & 1.0 \\
\hline & & 30 & 0.21 & 0.31 & 0.54 & 0.86 & 1.13 & 1.85 \\
\hline & & 60 & 0.51 & 0.83 & 1.02 & 1.8 & 2.3 & 4 \\
\hline & & 120 & 0.81 & 1.1 & 1.73 & 2.11 & 3.8 & 6.5 \\
\hline & & 240 & 0.96 & 1.86 & 2.77 & 3.3 & 6.0 & 8.0 \\
\hline & \multirow{5}{*}{ W.S } & 15 & 0.065 & 0.093 & 0.11 & 0.31 & 0.54 & 0.7 \\
\hline & & 30 & 0.38 & 0.43 & 0.51 & 0.65 & 0.83 & 1.0 \\
\hline & & 60 & 0.55 & 0.72 & 0.83 & 1.11 & 1.63 & 2.0 \\
\hline & & 120 & 0.67 & 0.87 & 1.05 & 1.89 & 3.05 & 4.3 \\
\hline & & 240 & 0.89 & 1.03 & 1.88 & 3.1 & 4.7 & 6.5 \\
\hline \multirow{10}{*}{$49^{0}$} & \multirow{5}{*}{ O.M.C } & 15 & 0.28 & 0.54 & 0.73 & 0.96 & 1.34 & 1.87 \\
\hline & & 30 & 0.81 & 0.97 & 1.23 & 1.88 & 2.65 & 3.3 \\
\hline & & 60 & 1.1 & 1.76 & 2.11 & 3.3 & 5.1 & 7.4 \\
\hline & & 120 & 1.74 & 2.87 & 4.1 & 6.8 & 9.2 & 11 \\
\hline & & 240 & 2.1 & 5.3 & 7.7 & 10.3 & 12.6 & 15 \\
\hline & \multirow{5}{*}{ W.S } & 15 & 0.37 & 0.5 & 0.73 & 0.89 & 1.08 & 1.5 \\
\hline & & 30 & 0.43 & 0.58 & 0.81 & 1.16 & 2.1 & 3.2 \\
\hline & & 60 & 0.61 & 0.87 & 1.0 & 2.03 & 3.61 & 5.4 \\
\hline & & 120 & 0.88 & 1.12 & 2.63 & 3.25 & 5.64 & 7.1 \\
\hline & & 240 & 1.81 & 3.33 & 4.92 & 6.71 & 8.6 & 10.0 \\
\hline \multirow{10}{*}{$60^{\circ}$} & \multirow{5}{*}{ O.M.C } & 15 & 0.83 & 1.32 & 2.43 & 4.74 & 6.56 & 8.47 \\
\hline & & 30 & 1.89 & 2.85 & 4.32 & 7.13 & 9.66 & 12.77 \\
\hline & & 60 & 4.9 & 7.4 & 9.71 & 11.65 & 15.13 & 18.65 \\
\hline & & 120 & 8.74 & 10.41 & 13.63 & 17.12 & 19 & 22.87 \\
\hline & & 240 & 13.34 & 15.0 & 17.31 & 19.08 & 23.1 & 27.0 \\
\hline & \multirow{5}{*}{ W.S } & 15 & 0.43 & 0.57 & 0.88 & 1.31 & 2.54 & 4.33 \\
\hline & & 30 & 0.73 & 0.95 & 2.0 & 3.6 & 5.4 & 7.8 \\
\hline & & 60 & 1.57 & 2.13 & 4.31 & 6.7 & 8.31 & 10.5 \\
\hline & & 120 & 2.88 & 4.11 & 6.34 & 8.87 & 11.21 & 13.6 \\
\hline & & 240 & 4.99 & 6.7 & 9.81 & 11.35 & 14.64 & 17.0 \\
\hline
\end{tabular}

\subsubsection{Loss in Gypsum Content.}

The losses in gypsum content increases with the rise in water temperature. These increases were found to be $(2.9,3.4$ and $4.8 \%)$ for samples compacted at W.S and subjected to water temperature of $\left(25^{\circ}, 49^{0}\right.$ and $\left.60^{\circ} \mathrm{C}\right)$ respectively, under $(1.2 \mathrm{~m} / \mathrm{sec})$ water velocity for (240 min.) flow duration. For samples compacted at OMC, the increasing in gypsum loss were $(3.7,4.5$ and $5.3 \%)$. 


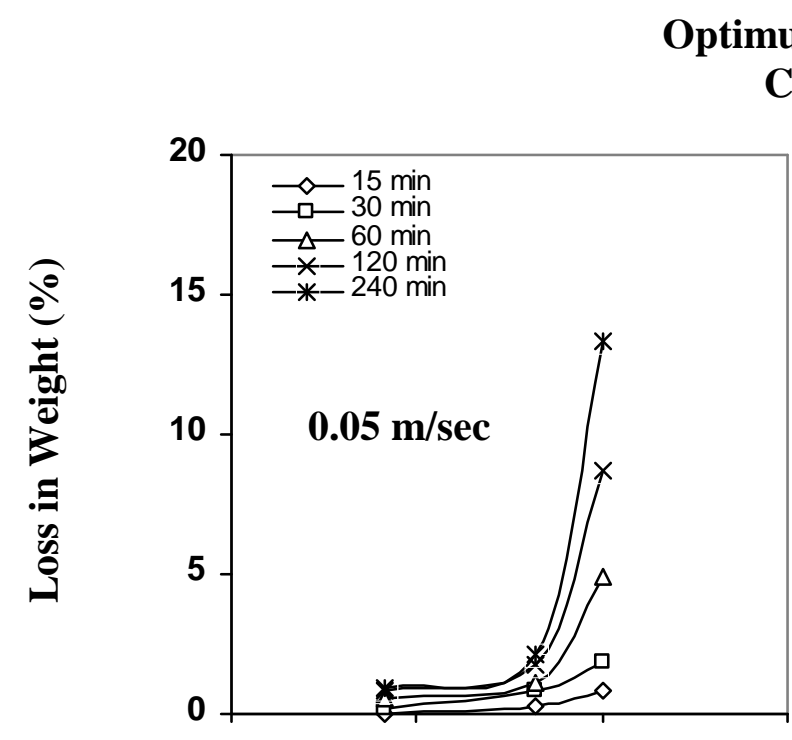

Moisture

Content
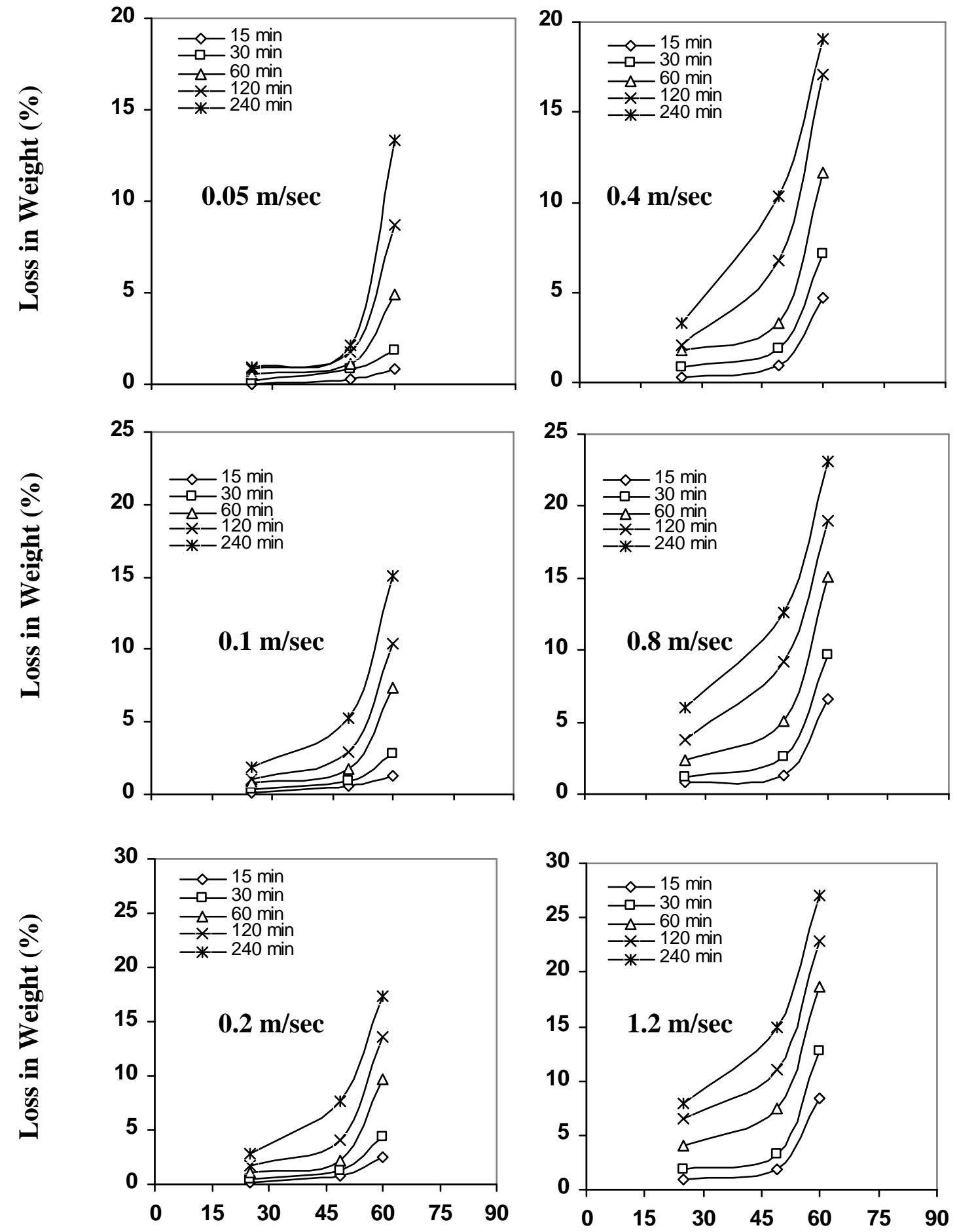

Water Temperature $\left(\mathbf{C}^{\mathbf{0}}\right)$

Water Temperature $\left(\mathbf{C}^{\mathbf{0}}\right)$

Fig. (7) Correlation between loss in weight and water temperature 


\section{Wet Side}
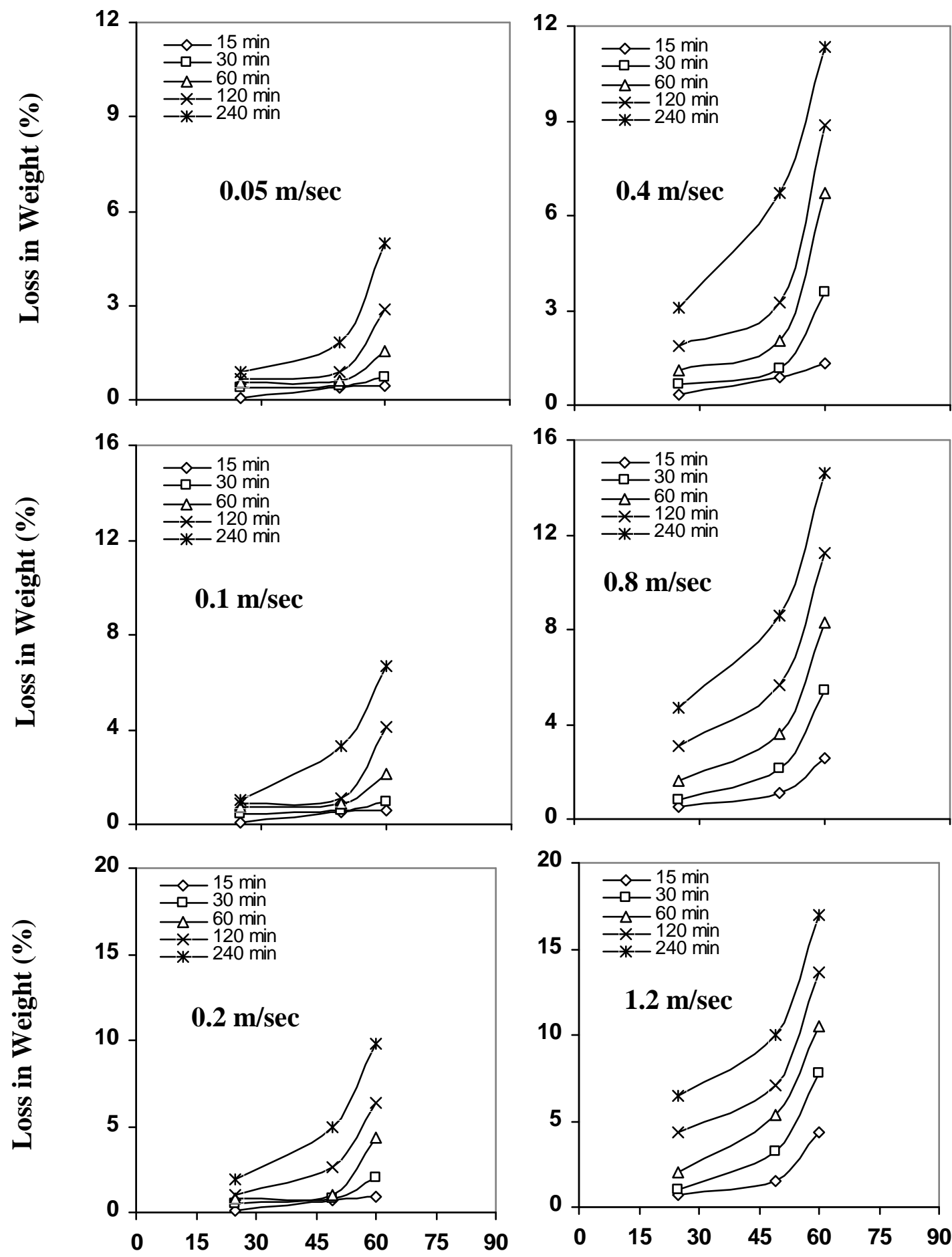

Water Temperature $\left(C^{0}\right)$

Water Temperature $\left(\mathbf{C}^{\mathbf{0}}\right)$

Fig. (8) Correlation between loss in weight and water temperature 
Optimum Water Content
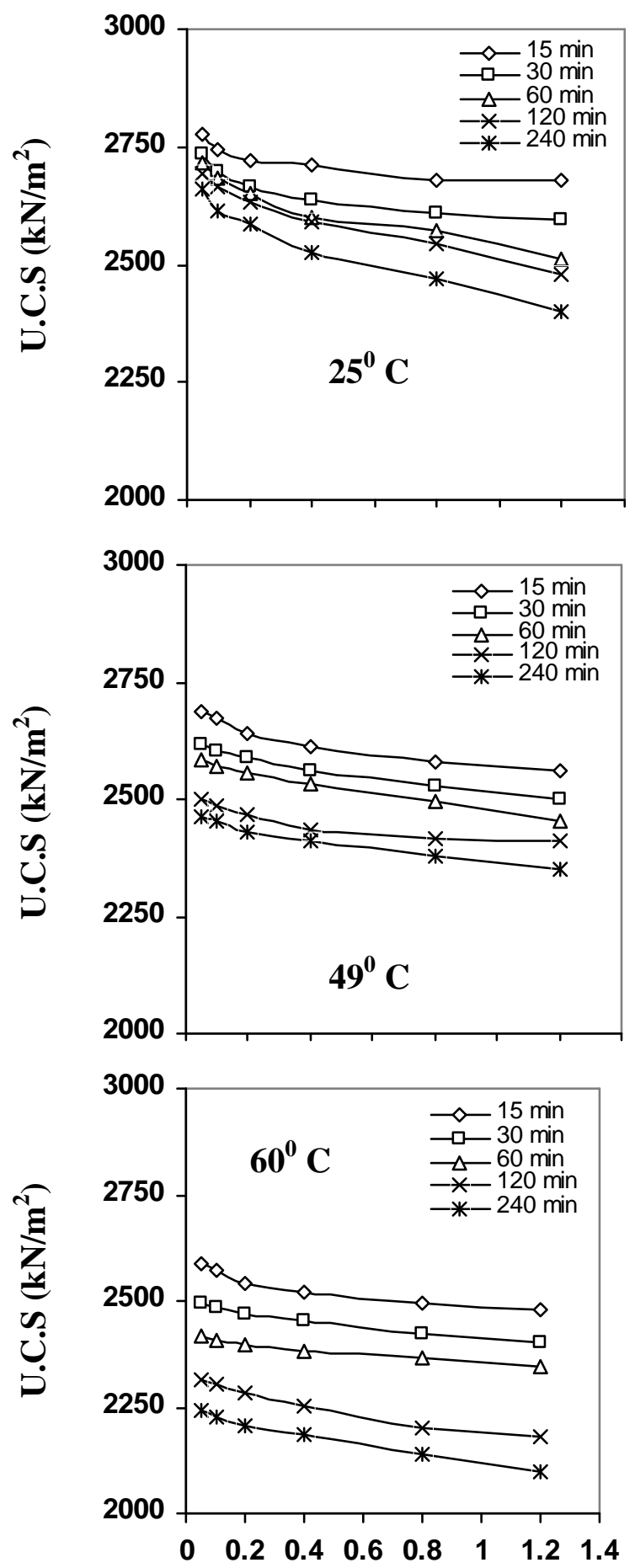

Water Velocity

$(\mathrm{m} / \mathrm{sec})$
Wet Side
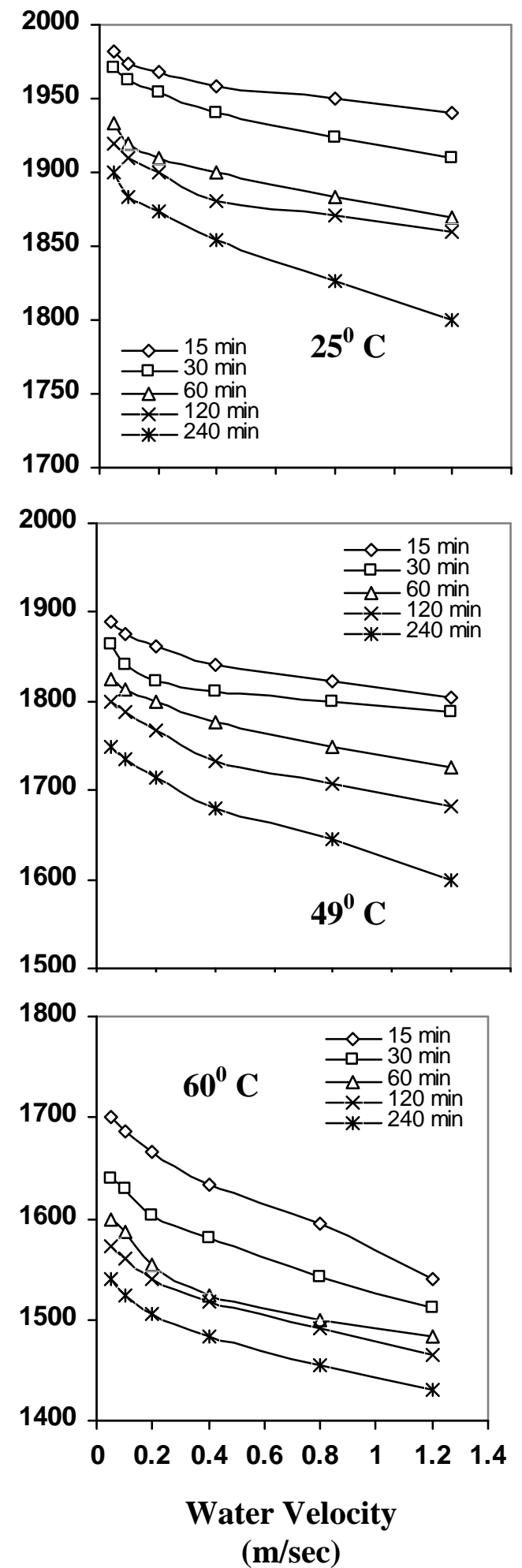

Fig. (9) Correlation between UCS and water velocity 


\section{Conclusions.}

1. Natural soil exhibit no strength resistance against erosion and failed rapidly during soaking.

2. Water temperature has significant effect on the unconfined compressive strength $\left(\mathrm{q}_{\mathrm{u}}\right)$ of lime stabilized samples. The strength increased with temperature increasing and decreased with low temperature.

3. The dissolved gypsum shows a gradual decreases with the soaking duration up to a certain limit, which after that shows insignificant changes.

4. The flow water velocity, temperature and duration causes an increasing losses in weight. Sudden increase in weight losses observed at temperature of $\left(49^{0} \mathrm{C}\right)$.

5. High water velocity causes decreasing in unconfined compressive strength, more loss in gypsum content, for all values of flow duration and water temperature.

References

1 Van Alphen, J. G. and Romero, F. D. R. (1971) “Gypsiferous Soils”, Bulletin -12, International Institute for Land Reclamation and Improvement, Wageningen, Holland.

2 Blight, G. E. (1976), "Migration of Subgrade Salts Damages thin Pavements" Proceeding of the American Society of Civil Engineers, ASCE, Transportation Engineering Journal, Vol. 102, No. TE4, pp.774-791.

3 FAO (1990) "Management of Gypsiferous Soil” Bull. No. 62, Rome, Italy.

$4 \quad$ Ping, X. and Beaudoin, J. J. (1992) "Mechanism of Sulfate Expansion Thermodynamic Principles of Crystallization Pressure", Cement Concrete Research, Vol.22, No.4, PP.631-640.

5 Mikheev, V. V. Petukhim, V. P. and Boldirev, G. V. (1977) "Deformability of Gypsous Soils" Proceedings of $9^{\text {th }}$ International Conference on soil Mech. and foundation Engg., Vol.1, pp.211-214.

6 Al-Zory E. A. (1993) " The Effect of Leaching on Lime Stabilized Gypseous Soil " M.Sc. Thesis, Civil Engineering Department, College of Engineering, University of Mosul.

7 Razouki, S. S.; Al-Omari, R. R.; Nashat, I. H.; Razouki, H. F. and Khalid, S. (1994), "The Problem of Gypsiferous Soils in Iraq", Proceeding of the Symposium on Gypsiferous Soils and Their Effect on Structures, NCCL, pp.7-33, Baghdad.

8 Al-Azawi, M. Z. (1998), "Effect of Surcharge Loads on Strength and Deformation Characteristics of Gypsiferous Soil for High ways and Airports" M. Sc. Thesis, Building and construction Department, University of Technology, Baghdad.

9 Kuttah, D. K. (2000), "Effect of Long-Term Soaking on Strength and Deformation Characteristics of a Clayey Gypsiferous Subgrade Soil", M. Sc. Thesis, Civil Engineering Department, College of Engineering, University of Al-Nahrain.

10 Razouki, S. S. and Kuttah, D. K. (2002) "Predictive Equation for Soaked CBR of Clayey Gypsiferous Soil” Engineering and Technology, Vol.21, No.8, pp.603-610. 
11 . Al-Rawi, M. Y. K. (2003), "Effect of Long-Term Soaking on the Engineering Properties of Gypsoues Soil", M. SC. Thesis, Civil Engineering Department, College of Engineering, University of Mosul.

12 Kemper, W. D.; Olsen, J. and Demooy, C. J. (1975), "Dissolution Rate of Gypsum in Flowing Water", Soil Science Society of America Journal, Vol.39, pp.458 - 464.

13 Keren, R. and Connor, G. A. (1982), "Gypsum Dissolution and Sodic Soil Reclamation as Affected by Water Flow Velocity", Soil Science. Society of. America Journal, Vol.46, pp.726 - 732 .

14 Porter, E. T., Snaford, L. P. and Suttles, S. E. (2000) "Gypsum Dissolution is not a Universal Integrator of Water Motion", America Society of Limnology and Oceanography, Vol.45, No. 1 pp.145 - 158.

15 James, A. N. and Kirkpatrick, I. M. (1980)“Design Of Foundation Of Dams Containing Soluble Rocks And Soils". Quarterly journal of engineering geology , London ,Vol.13, pp.188-198.

. 16 James, A. N. and Lupton A. R. R. (1978) "Gypsum and Anhydrite in Foundations of Hydraulic Structures” Journal of Geotechnical Engg., ASCE, Vol.28, No.3, pp.249-272.

17 Al-Obydi, M. A. (1992) "Lime Stabilization of Gypseous Soils", M.Sc. Thesis, Civil Engineering Department, College of Engineering, University of Mosul.

Little, D.N. (1995) "Handbook for Stabilization of Pavement Sub Grade and Base Courses with Lime", Kendall Hunt Publishing Company, Iowa, USA, by National Lime Association.

19 Al - Aarrajy, H. S. S. (2008) "Solubility And Erosion In Some Types Of Soluble Rocks", M.Sc. Thesis, Civil Engineering Department, College of Engineering, University of Mosul.

20 Hunter, D. (1988) "Lime-Induced Heave in Sulfate-Bearing Clay Soils", Journal of Geotechnical Engg., ASCE, Vol.114, No.2, PP.150-167.

21 Elorza, M.G. and Santolalla, F.G. (1998), "Geomorphology of the Tertiary Gypsum Formations in the Ebro Depression". GEODERMA Journal, Vol.87, No.1, pp.1-29. 